\title{
Molecular Diversity of Phytoplasmas Associated with Grapevine Yellows Disease in North-Eastern Italy
}

\author{
Yuri Zambon, Alessandro Canel, Assunta Bertaccini, and Nicoletta Contaldo ${ }^{\dagger}$
}

Alma Mater Studiorum, University of Bologna, DipSA, Plant Pathology, Viale G. Fanin, 42, 40127 Bologna, Italy. Accepted for publication 11 September 2017.

\begin{abstract}
A 3-year survey was conducted in Northern Italy to verify the presence and diversity of phytoplasmas in selected vineyards showing symptoms of severe yellows. Symptomatic and asymptomatic grapevines were sampled, and insects were collected using yellow sticky traps. The phytoplasmas detected in grapevine samples were different according to the years: "flavescence dorée" $(16 \mathrm{SrV}-\mathrm{C} / \mathrm{D})$ was detected together with other phytoplasmas such as 16SrXII-A ('Candidatus Phytoplasma solani'related, bois noir), $16 \mathrm{SrI}-\mathrm{B}$ ('Ca. P. asteris'-related, aster yellows), $16 \mathrm{SrX}-\mathrm{B}$ ('Ca. P. prunorum'-related, European stone fruit yellows), and 16SrV-A ('Ca. P. ulmi'-related, elm yellows). Moreover, phytoplasmas belonging to 16SrVII-A ('Ca. P. fraxini'-related) and 16SrVI ('Ca. P. trifolii'-related)

subgroups were also identified. Identification of phytoplasmas was also carried out from insects and showed the presence of some of these phytoplasmas in Scaphoideus titanus and Orientus ishidae: 16SrXII-A, 16SrVII, and 16SrVI phytoplasmas were detected in specimens of both species, while 16SrXII-A and 16SrI-B phytoplasma strains were identified in Orientus ishidae and Hyalesthes obsoletus, and $16 \mathrm{SrX}-\mathrm{B}$ in S. titanus. Direct sequencing of selected amplicons obtained from $16 S r R N A, r p$, and tuf genes from grapevine and insect samples confirmed the phytoplasma identification. The 16SrVII-A and 16SrVI phytoplasmas were never detected before in grapevine, S. titanus and Orientus ishidae in Europe and their epidemiological importance is being monitored.
\end{abstract}

Phytoplasmas are biotrophic plant-pathogenic wall-less prokaryotes belonging to the class mollicutes with a low $\mathrm{G}+\mathrm{C}$ content, closely related to Gram-positive bacteria. They are phloem-limited and mainly transmitted by insects belonging to leafhopper (Cicadellidae), planthopper (Cixiidae), or psyllid (Psyllidae) families (Weintraub and Beanland 2006). Phytoplasmas are associated with several diseases affecting economically important crop species such as grapevine, coconut palm, fruit trees, vegetables, and ornamental plants all over the world (Bertaccini et al. 2014). Based on analysis of 16S rRNA gene, they are classified into 33 groups and 40 'Candidatus Phytoplasma' species (Dermastia et al. 2017; IRPCM 2004) according to restriction fragment length polymorphism (RFLP) pattern and to percentage of sequence homology, respectively, of 1,200 nt in this gene (Lee et al. 1998a; Wei et al. 2007; Zhao et al. 2009).

Grapevine yellows (GYs) is one of the most damaging phytoplasmaassociated diseases that can cause severe yield losses in every geographic area where grapevines are cultivated in the world (Constable 2010). Despite presence of different phytoplasmas in the diseased plants (Dermastia et al. 2017), the typical symptoms caused by these phytoplasmas, including leaf reddening and rolling, abnormal lignification of canes, short internodes, and flower abortion, are the same. The main yellows diseases in grapevine in Europe are "flavescence dorée" (FD, 16SrV-C/D ribosomal subgroups) (Bertaccini et al. 1995; Martini et al. 1999) and bois noir (BN, 'Candidatus Phytoplasma solani', 16SrXII-A ribosomal subgroup) (Quaglino et al. 2013), transmitted by the monovoltive ampelophagous leafhopper Scaphoideus titanus Ball and by the polyphagous cixiid Hyalestes obsoletus Signoret, respectively (Schvester et al. 1961; Sforza et al. 1998). More recently in Europe, $16 \mathrm{SrV}-\mathrm{C}$ phytoplasmas linked to FD presence in grapevine

†Corresponding author: N. Contaldo; E-mail: nicoletta.contaldo2@unibo.it

GenBank accession numbers KY454858 to KY454865, KY464914 to KY464918, and KY457236.

(c) 2018 The American Phytopathological Society were detected in different weed species such as Clematis vitalba, Alnus glutinosa, Sambucus nigra, Cornus sanguinosa, Prunus spinosa, Ulmus glabra, Ulmus minor, Ulmus spp., Corylus avellane, and Salix sp. (Angelini et al. 2004; Casati et al. 2017; Filippin et al. 2005, 2009; Maixner et al. 2000). On the other hand, stolbur-related phytoplasmas (16SrXII-A, molecularly undistinguishable from $\mathrm{BN}$ ) have been reported in a wide range of crops and wild plants including solanaceous, lavender, strawberry, sugar beet, stinging nettles (Urtica dioica), and bindweed (Convolvolus arvensis) (Borgo et al. 2008; Lessio et al. 2007; Maixner et al. 1995; Marcone et al. 1997; Škorić et al. 1998).

During the last 25 years, the use of molecular techniques such as PCR/RFLP and DNA sequencing allowed the detection and characterization of phytoplasmas associated with GYs and led to identification and classification schemes for phytoplasmas (Bertaccini et al. 1995; Lee et al. 1998a; Martini et al. 1999). The FD-associated phytoplasma strains belonging to ribosomal subgroups $16 \mathrm{SrV}-\mathrm{C}$ and $16 \mathrm{SrV}-\mathrm{D}$ were further differentiated using polymorphisms in $r p S 3$ and in secY genes (Angelini et al. 2001; Arnaud et al. 2007; Martini et al. 2002; Quaglino et al. 2010). Moreover, multigene analyses of $\mathrm{BN}$-associated phytoplasmas, based on tuf (Langer and Maixner 2004), secY, vmpl (Fialova et al. 2009), and stamp (Fabre et al. 2011) genes, have highlighted the presence of several phytoplasma lineages (Foissac and Maixner 2013).

Grapevine phytoplasma control strategies in Europe are mainly directed to control FD and are based on prevention, surveys, and insecticide treatments against $S$. titanus; however, other insects may play a role in transmitting these phytoplasmas. It was shown that Dictyophara europaea (L.) (Hemiptera; Dictyopharidae) transmits phytoplasmas from Clematis vitalba L. to grapevines under experimental conditions (Filippin et al. 2009), and Oncopsis alni (Schrank) (Cicadellidae; Macropsinae) can transmit 16SrV-C from alder to grapevine, inducing Palatinate grapevine yellows (PGY) (Maixner et al. 2000). The monitoring of insect species that are particularly abundant in vineyards and could serve as new potential vectors is also relevant in the management of GY diseases. Recently the mosaic leafhopper Orientus ishidae (Matsumura) (Cicadellidae; Deltocephalinae) was found to be positive for $16 \mathrm{SrV}-\mathrm{C}$ and $-\mathrm{D}$ 
phytoplasmas in Slovenia, Italy, and Switzerland (Gaffuri et al. 2011; Mehle et al. 2010; 2011; Trivellone et al. 2015); it was also shown capable to transmit $16 \mathrm{SrV}$ phytoplasmas from broad bean to grapevine (Lessio et al. 2016).

Despite several years of monitoring and mandatory control against $S$. titanus, and the almost exclusive cultivation of a GYtolerant grapevine cultivar (Glera), these diseases in North-Eastern Italy (Veneto) are still showing epidemic spreading (Canel et al. 2014). Cultivar Glera has been reported to show recovery from phytoplasma infection (Angelini et al. 2006; Carraro et al. 2004) potentially increasing the presence of asymptomatic phytoplasmainfected grapevine plants that could serve as an inoculum reservoir.

To verify the reasons of the continuous GY spreading in Veneto region (North-Eastern Italy), especially in Treviso Province, Prosecco areas, where cultivar Glera is long-time cultivated for producing the famous sparkling wine, the identification and molecular characterization of phytoplasmas in symptomatic and asymptomatic grapevine and insects captured in selected vineyards during a 3-year survey is reported. In particular, the focus was to evaluate the possible role of asymptomatic grapevine plants and of recently reported insect vectors in the selected ecosystem.

\section{MATERIALS AND METHODS}

Plant and insect samples. Samples belonging to four grapevine cultivars (Chardonnay, Glera, Pinot Gris, and Perera) were collected from 2013 to 2015 in 17 vineyards, 15 to 20 years old, located in the Treviso Province (North-Eastern Italy, Fig. 1) at levels ranging from 253 (Valdobbiadene) to $13 \mathrm{~m}$ above sea level (Oderzo) for a total surface of about 100 ha. The sampling was carried out randomly every year from different plants. Insects were also captured by yellow sticky traps in the same vineyards and identified under a stereomicroscope using dichotomous keys (Pollini 2013), and potential vector species were detached from glue and grouped in batches containing one to two adult individuals of Scaphoideus titanus Ball, Hyalestes obsoletus Signoret, Orientus ishidae (Matsumura 1902), and Hishimonus hamatus Kuoh.

DNA extraction and phytoplasma identification. Total nucleic acids were extracted from $1 \mathrm{~g}$ of fresh plant tissue (leaf midribs) from 137 symptomatic and 24 asymptomatic grapevines (20 of which were collected in 2015), and ground in liquid nitrogen using a phenol/chloroform protocol (Prince et al. 1993). Following a CTAB-based DNA extraction procedure (Angelini et al. 2001), 29 batches of S. titanus (50 individuals), 27 of Hyalestes obsoletus
(32 individuals), 69 of Orientus ishidae (89 individuals), and 2 of Hishimonus hamatus (4 individuals) were ground in Eppendorf tubes and processed for molecular analyses to verify the presence of phytoplasmas. Plant nucleic acid was diluted in sterile deionized water to a final concentration of $20 \mathrm{ng} / \mu \mathrm{l}$, while $1 \mu \mathrm{l}$ of sterile waterdiluted (1:30) insect DNA was used in PCR assays performed using phytoplasma universal primer pair P1/P7 (Deng and Hiruki1991; Schneider et al. 1995), followed by nested PCR on 1:29 dilution of the obtained amplicons $(1 \mu \mathrm{l})$ with primers B5/P7 (Padovan et al. $1995)$ or with primers $16 \mathrm{R}_{758} \mathrm{f} / 23 \mathrm{SR}_{1804}$ (=M1/B6) (Gibb et al. 1995; Padovan et al. 1995), which amplify a fragment of about $1,000 \mathrm{bp}$ from the $16 S$ rRNA gene, the spacer region, and the beginning of $23 \mathrm{~S}$ rRNA gene. Additional nested PCR assays were carried out using group specific primers R16(I)F1/R1 (Lee et al. 1994) or U5/U3 (Lorenz et al. 1995) on P1/P7 dilution 1:29. Samples lacking DNA were run as negative controls, and DNAs extracted from periwinkle maintained in micropropagation (Bertaccini 2014) were used as positive controls. Each reaction was performed in a total volume of $25 \mu$ l containing $2.5 \mu$ of the $10 \times$ buffer, $200 \mu \mathrm{M}$ of dNTP, $0.625 \mathrm{U}$ of Taq polymerase (Sigma Aldrich), and $0.4 \mu \mathrm{M}$ of primer pair. The PCR conditions for the 35 cycles were as follows: $1 \mathrm{~min}$ ( $2 \mathrm{~min}$ for the first cycle) denaturation at $94^{\circ} \mathrm{C}, 2 \mathrm{~min}$ annealing at $55^{\circ} \mathrm{C}\left(50^{\circ} \mathrm{C}\right.$ for the nested PCR $)$, and $3 \mathrm{~min}$ (10 min for the last cycle) at $72^{\circ} \mathrm{C}$ for primer extension. Six microliters of each PCR product was separated by electrophoresis in $1 \%$ agarose gels, stained with ethidium bromide, and photographed under ultraviolet illumination $(312 \mathrm{~nm})$. Identification of detected phytoplasmas was done by RFLP analyses on 100 to $200 \mathrm{ng}$ of DNA amplicons with TrulI, TaqI, RsaI, and HhaI restriction enzymes (Fermentas, Vilnius, Lithuania) according to the manufacturer's instructions. The digested DNA fragments were separated by electrophoresis in a $6.7 \%$ polyacrylamide gel, stained with ethidium bromide, and visualized as reported above. Further, semi-nested PCR on P1/P7 amplicons using the primer pair P1/Tint (Smart et al. 1996) was also employed for full $16 \mathrm{~S}$ ribosomal gene sequence analyses.

Phytoplasma molecular characterization. FD strains. Molecular variability of FD phytoplasma strains was studied on 22 grapevines and four Orientus ishidae on $r p$, secY, and tuf genes. PCR analyses on $r p$ gene were carried out using group $16 \mathrm{SrV}$ specific primers $\mathrm{rp}(\mathrm{V}) \mathrm{F} 1 / \mathrm{rp}(\mathrm{V}) \mathrm{R} 1$, followed by nested PCR with rp (V)F1A/rp(V)R1A (Lee et al. 2004) or rp(V)F1A/rp(V)R1primer combinations (Table 1). Each reaction was performed in a total volume of $25 \mu \mathrm{l}$ as described above with annealing at $50^{\circ} \mathrm{C}$.

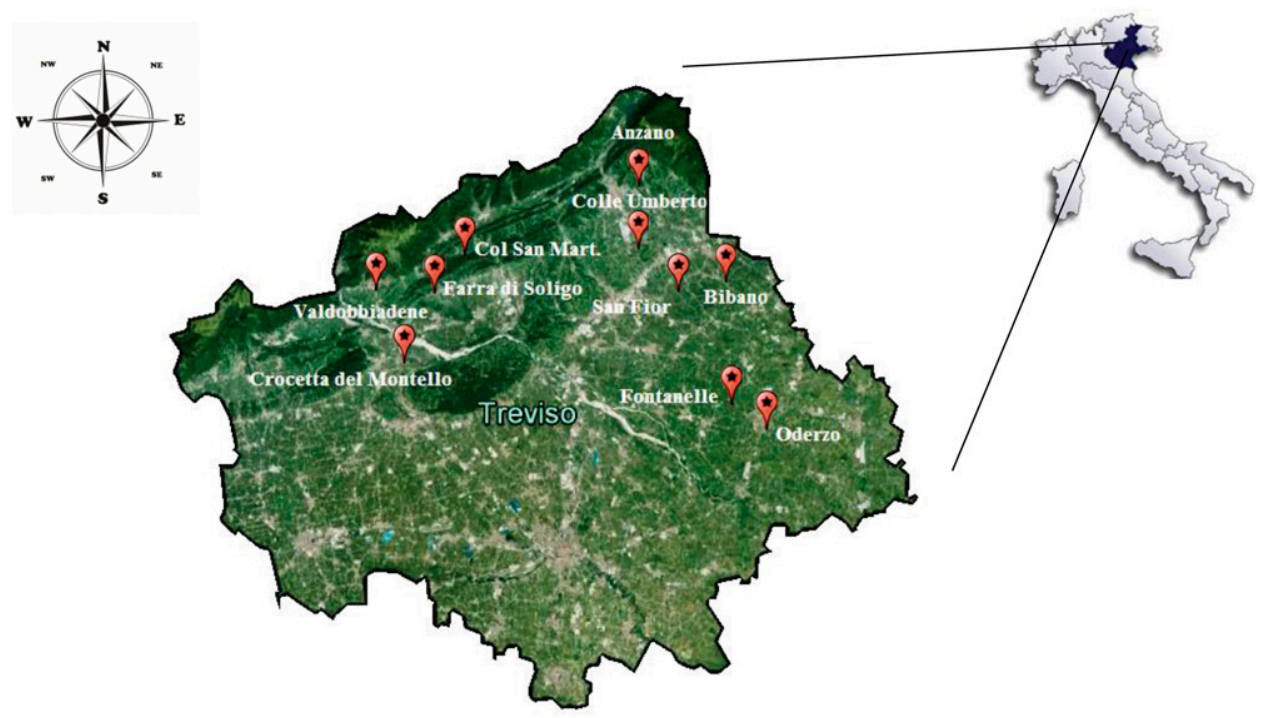

Fig. 1. Map of Treviso Province: the locations of sampling are indicated by dots. 
Amplifications of $\sec Y$ gene were performed using the primer pairs FD9F2/FD9R in direct and FD9F3/FDR2 in a nested PCR following reported conditions (Angelini et al. 2001). Tuf gene amplification was carried out using a cocktail of degenerate primers in a nested PCR (Makarova et al. 2012). The single gene characterization was achieved by RFLP analyses using TrulI, Tsp509I, TaqI, and Alf1 restriction enzymes according to the amplicon studied. The obtained restriction profiles were compared with published reference strains FD70, TV54, and BO13 (Botti and Bertaccini 2007).

$B N$ strains. Molecular characterization of $\mathrm{BN}$ phytoplasma strains from six grapevines, seven Hyalestes obsoletus, and three Orientus ishidae samples was performed on tuf, stamp, and secY genes. The tuf gene was amplified in a nested PCR procedure using specific primer pairs Tuf1f/r and TufAYf/r (Langer and Maixner 2004) and amplicons were subjected to RFLP analyses with HpaII. Amplicons produced on stamp (Fabre et al. 2011) and secY (Lee et al. 2010) genes were subjected to RFLP analyses with TrulI enzyme.

Other phytoplasma strains. Phytoplasma strains belonging to $16 \mathrm{SrVI}$ and $16 \mathrm{SrVII}$ ribosomal groups detected in grapevine, $S$. titanus and Orientus ishidae were characterized on $r p$ gene, using the primer set rpF1/rpR1 (Lim and Sears 1992) followed by nested PCR by rpVIF2/rpVIR2 and rpVIIIF2/rpVIIIR2 primers (Martini et al. 2007), respectively, and amplicons were subjected to TrulI restriction analysis.

Sequencing and phylogenetic analyses. Direct sequencing of 14 selected nested PCR products obtained from different genes including the $16 \mathrm{~S} r R N A$ gene was performed in both directions with the same primers used in their nested amplification. Sequences were assembled using the Staden program package (Staden et al. 2000), aligned with Clustal X (Thompson et al. 1997), and deposited in GenBank (Table 2). P1/Tint sequences obtained from grapevine samples were subjected to virtual RFLP analyses on the R16F2n/R2 (Gundersen and Lee 1996; Lee et al. 1995) amplicons (1,250 bp) for group and subgroup classification, and nucleotide sequence identity comparison using the $i$ Phyclassifier (Zhao et al. 2009). Multiple alignments were performed using CLUSTAL W (Thompson et al. 1994), and the evolutionary history was inferred using the neighborjoining method (Saitou and Nei 1987). The evolutionary distances were computed using the maximum composite likelihood method (Tamura et al. 2004). Evolutionary analyses were conducted in MEGA6 (Tamura et al. 2013) to determine phylogenetic relationships.

\section{RESULTS}

Phytoplasma molecular characterization. The survey was carried out in the same 17 vineyards over the 3 -year monitoring with a random sampling on symptomatic plants in 2013 and 2014 and on both symptomatic and asymptomatic plants in 2015. In 2013, 70\% of the 44 grapevine samples tested were positive for the presence of phytoplasmas, and most of them (90\%) resulted from infections by $16 \mathrm{SrV}-\mathrm{C}$ and $16 \mathrm{SrV}-\mathrm{D}$ phytoplasmas (FD). The samples detected positive for the presence of BN phytoplasma (16SrXII-A) increased from $2 \%$ in 2013 to $12 \%$ in 2014 (Fig. 2), while FD strains prevalence decreased to $58 \%$ on a total of $56 \%$ of positive samples. The increase/decrease was not location specific or grapevine cultivar specific. In 2015, the samples that tested positive were $65 \%$ including those from asymptomatic plants. In particular, 20 of the 76 samples tested were asymptomatic and the presence of phytoplasma strains belonging to 16SrVI (four samples) and 16SrVII ribosomal group (nine samples), both in single and in mixed infection, was detected in the majority of them (Table 3 ). In particular, phytoplasmas belonging to group 16SrVI were detected in samples from three vineyards of cultivar Glera, while those belonging to group $16 \mathrm{SrVII}$ were found in six vineyards of cultivars Glera, Chardonnay, and Perera. In the overall survey, FD and BN phytoplasmas were detected in $51 \%$ of the symptomatic plants, and occasionally also in asymptomatic plants $(3 \%)$ irrespective of the cultivar. Moreover, phytoplasmas belonging to ribosomal groups $16 \mathrm{SrI}-\mathrm{B}, 16 \mathrm{SrV}-\mathrm{A}$, and $16 \mathrm{SrX}-\mathrm{B}$ were occasionally detected in 12 samples (Table 3; Fig. 2). In particular, three 16SrI-B and four $16 \mathrm{SrX}-\mathrm{B}$ phytoplasmas were identified in asymptomatic plants.

Insect specimens. The number of insects captured was variable according to the management of the vineyards (organic/ conventional) and the presence of forest and woody plants in the surroundings. The monitoring detected the presence of $S$. titanus $(52,5 \%)$, followed by Orientus ishidae (37\%) and Hyalestes obsoletus (10\%); in particular, 350 S. titanus, 229 Orientus ishidae, 57 Hyalestes obsoletus, and 2 Hishimonus hamatus specimens were captured and identified. Of those captured specimens, $50 \mathrm{~S}$. titanus, 32 Hyalestes obsoletus, 89 Orientus ishidae, and 4 Hishimonus hamatus were subjected to molecular analysis in batches each with one to two individuals. Nested PCR assays on the 16S rDNA allowed identification of phytoplasma presence in all insect species analyzed, except in Hishimonus hamatus (Table 3). The $48 \%$ of S. titanus (14 specimens), $30 \%$ of Orientus ishidae (22), and $38 \%$ of

TABLE 1. Restriction profiles of $16 S r R N A, r p$, tuf, and $\sec Y$ genes on "flavescence dorée" (FD)-infected samples from grapevine and from elm yellows phytoplasma (16SrV-A) DNA from periwinkle maintained in micropropagation ${ }^{\mathrm{z}}$

\begin{tabular}{|c|c|c|c|c|c|c|c|c|c|c|c|}
\hline \multirow[b]{3}{*}{ Samples } & \multirow[b]{3}{*}{$16 \mathrm{Sr}$} & \multicolumn{9}{|c|}{ RFLP profiles } & \multirow[b]{3}{*}{ Lineages } \\
\hline & & \multicolumn{2}{|c|}{ Gene $r p \bullet$} & \multicolumn{3}{|c|}{ Gene $r p^{*}$} & \multirow{2}{*}{$\frac{\text { Gene } t u f}{A l f \mathrm{I}}$} & \multicolumn{3}{|c|}{ Gene $\sec Y$} & \\
\hline & & TruII & Tsp509I & TrulI & Tsp509I & $\overline{T a q I}$ & & TrulI & Tsp509I & $\overline{T a q \mathrm{I}}$ & \\
\hline Grapevine 6 bariv & $\mathrm{V}-\mathrm{C}$ & A & A & $\mathrm{D}$ & B & $\mathrm{D}$ & A & A & A & $\mathrm{C}$ & $\mathrm{b}$ \\
\hline Grapevine valdo 1 & $\mathrm{~V}-\mathrm{C}$ & A & A & $\mathrm{E}$ & A & E & $A+B$ & A & B & B & $\mathrm{c}$ \\
\hline Grapevine crocetta 1 & $\mathrm{~V}-\mathrm{C}$ & A & A & $\mathrm{D}$ & A & $\mathrm{D}$ & A & A & B & A & a \\
\hline Grapevine bar* & $\mathrm{V}-\mathrm{C}$ & A & A & $\mathrm{D}$ & B & $\mathrm{D}$ & A & B & B & A & $\mathrm{d}$ \\
\hline Grapevine 7 bariv & V-D & $\mathrm{B}$ & A & A & A & A & $\mathrm{B}$ & $\mathrm{D}$ & $\mathrm{D}$ & $\mathrm{D}$ & $\mathrm{g}$ \\
\hline Grapevine anzano 3 & V-D & B & A & A & A & A & B & $\mathrm{D}$ & $\mathrm{D}$ & $\mathrm{D}$ & $\mathrm{g}$ \\
\hline Grapevine anzano 2 & V-D & B & A & A & A & A & $\mathrm{B}$ & $\mathrm{D}$ & $\mathrm{D}$ & $\mathrm{D}$ & $\mathrm{g}$ \\
\hline Grapevine fonte 3 & V-D & B & A & A & B & A & B & $\mathrm{D}$ & $\mathrm{D} / \mathrm{E}$ & $\mathrm{D}$ & $\mathrm{h}$ \\
\hline Grapevine crocetta 4 & V-D & B & A & B & A & B & B & $\mathrm{D}$ & $\mathrm{D}$ & $\mathrm{D}$ & $\mathrm{i}$ \\
\hline Orientus ishidae & $\mathrm{V}-\mathrm{C}$ & - & - & - & - & - & A & - & - & - & n.d. \\
\hline Periwinkle EY & V-A & $\mathrm{C}$ & B & $\mathrm{F}$ & $\mathrm{D}$ & $\mathrm{F}$ & A & $\mathrm{F}$ & $\mathrm{F}$ & E & 1 \\
\hline
\end{tabular}

${ }_{\mathrm{z}}$ Identical letters indicate identical restriction fragment length polymorphism (RFLP) profile; -, no amplicon obtained; n.d., lineage not determined; rp•, rp(V)

$\mathrm{F} 1 \mathrm{~A} / \mathrm{rp}(\mathrm{V}) \mathrm{R} 1 \mathrm{~A}$; and rp*, rp(V)F1A/rpR1 amplicons. Strains marked with * refer to reference profiles reported in Botti and Bertaccini (2007). 
Hyalestes obsoletus (10) batches tested positive for the presence of phytoplasmas. Specifically, $16 \mathrm{SrV}-\mathrm{C}$ was detected in two batches of $S$. titanus and four batches of Orientus ishidae, while 16SrXII-A was found in four batches of S. titanus, seven batches of Orientus ishidae, and six batches of Hyalestes obsoletus. Moreover, 16SrX-

TABLE 2. GenBank accession numbers of the sequences obtained for selected samples of grapevine and insects

\begin{tabular}{|c|c|c|c|c|}
\hline \multirow[b]{2}{*}{ Samples } & \multirow{2}{*}{$\begin{array}{l}\text { Ribosomal } \\
\text { group/ } \\
\text { subgroup }\end{array}$} & \multicolumn{3}{|c|}{$\begin{array}{c}\text { GenBank accession } \\
\text { numbers }\end{array}$} \\
\hline & & $\begin{array}{l}\text { Gene } 16 S \\
\quad r R N A\end{array}$ & Gene $r p$ & $\begin{array}{l}\text { Gene } \\
\text { tuf }\end{array}$ \\
\hline Grapevine 7B & 16SrVII-A & KY454858 & - & - \\
\hline Grapevine 7A & 16SrVI & KY454859 & KY464914 & - \\
\hline Grapevine 13B & $16 \mathrm{SrVII}$ & KY454860 & KY457236 & - \\
\hline Grapevine 9B & 16SrVI & KY454861 & - & - \\
\hline Grapevine $3 \mathrm{Y}$ & 16SrVII & KY454862 & - & - \\
\hline $\begin{array}{l}\text { Orientus } \\
\text { ishidae } 4 \mathrm{Y}\end{array}$ & $16 \mathrm{SrV}-\mathrm{C}$ & KY454863 & - & KY464918 \\
\hline $\begin{array}{l}\text { Orientus } \\
\quad \text { ishidae3B } \\
\text { Scaphoideus }\end{array}$ & 16 SrVII & KY454864 & KY464915 & - \\
\hline titanus $2 \mathrm{~A}(2)$ & 16SrVII & KY454865 & KY464917 & - \\
\hline S. titanus $1 \mathrm{~A}(3)$ & $16 \mathrm{SrVI}$ & - & KY464916 & - \\
\hline
\end{tabular}

B was detected in two batches of S. titanus; $16 \mathrm{SrI}-\mathrm{B}$ in two of S. titanus, three of Orientus ishidae, and four of Hyalestes obsoletus; 16SrVII was identified in eight insect batches, three of $S$. titanus and five of Orientus ishidae, while 16SrVI was detected in one batch of $S$. titanus and one batch of Orientus ishidae (Table 3).

FD strains. The multigene analysis on $t u f$, $\sec Y$, and $r p$ genes was carried out for 12 strains identified as $16 \mathrm{SrV}-\mathrm{C}$ and for 11 strains identified as $16 \mathrm{SrV}-\mathrm{D}$ collected in grapevines from 9 of the 17 vineyards surveyed. RFLP analyses on tuf gene showed the presence of two profiles for phytoplasma strains belonging to both FD ribosomal subgroups, while higher molecular variability was detected on secY gene in six $16 \mathrm{SrV}-\mathrm{C}$ and two $16 \mathrm{SrV}-\mathrm{D}$ strains. The RFLP analyses carried out with TrulI and Tsp509I restriction enzymes on the amplicons obtained with the primer pairs $\operatorname{rp}(\mathrm{V})$ F1A/rpR1 showed a higher variability when compared with the parallel analyses carried out on $\mathrm{rp}(\mathrm{V}) \mathrm{F} 1 \mathrm{~A} / \mathrm{rp}(\mathrm{V}) \mathrm{R} 1 \mathrm{~A}$ amplicons. In the first case, five different profiles in $16 \mathrm{SrV}-\mathrm{C}$ strains and three profiles in $16 \mathrm{SrV}-\mathrm{D}$ strains were obtained in comparison with a unique profile detected in the strains from both subgroups when amplified with the latter primer pairs (Table 1; Fig. 3). The comprehensive analyses of the restriction profiles obtained from the three genes allowed the identification of five lineages in $16 \mathrm{SrV}-\mathrm{C}$ FD strains and four for $16 \mathrm{SrV}$-D phytoplasmas (Table 1). Among

\section{3}

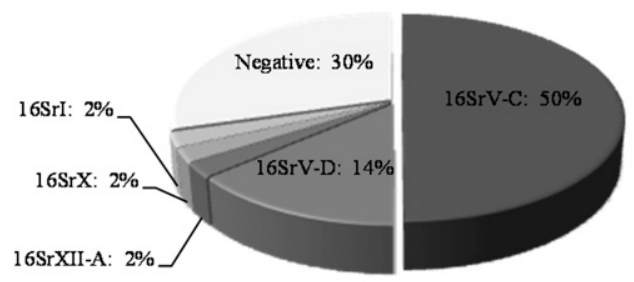

2014

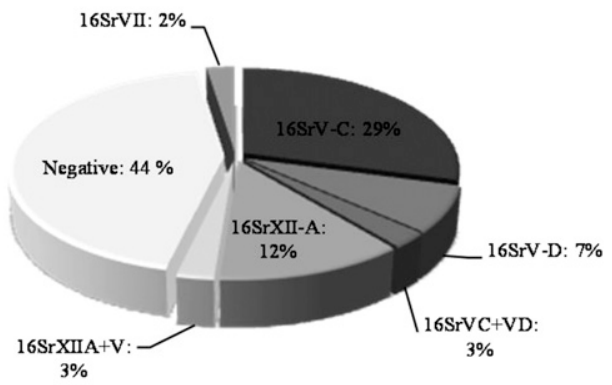

2015

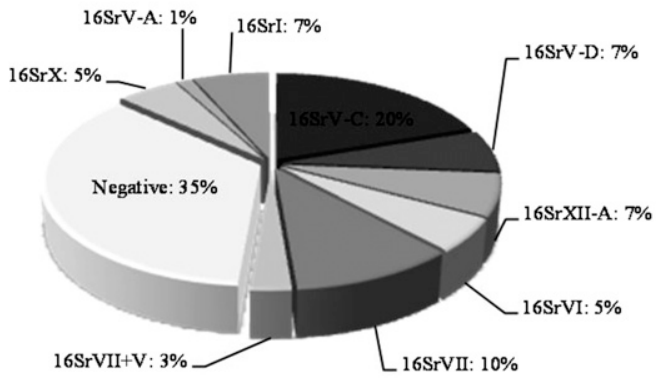

Fig. 2. Phytoplasma percentages detected by nested PCR/restriction fragment length polymorphism analyses on grapevine samples tested in the 2013 to 2015 survey.

TABLE 3. Phytoplasma identified in plants and insect samples collected in vineyards Treviso Province during 2013 to 2015

\begin{tabular}{|c|c|c|c|c|c|c|c|c|c|c|c|c|c|}
\hline \multirow[b]{2}{*}{ Samples ${ }^{z}$} & \multirow{2}{*}{$\begin{array}{c}\text { Number of } \\
\text { samples collected }\end{array}$} & \multirow{2}{*}{$\begin{array}{c}\text { Number of } \\
\text { positive samples }\end{array}$} & \multicolumn{11}{|c|}{$16 \mathrm{Sr}$ group/subgroup } \\
\hline & & & $\overline{\mathrm{V}-\mathrm{C}}$ & V-D & XII-A & VII-A & VI & X-B & I-B & $\mathrm{V}-\mathrm{C}+\mathrm{V}-\mathrm{D}$ & $\mathrm{V}-\mathrm{C}+\mathrm{XII}-\mathrm{A}$ & $\mathrm{V}-\mathrm{C}+\mathrm{VII}-\mathrm{A}$ & $\overline{V-A}$ \\
\hline Grapevines & 161 & 103 & 49 & 14 & 11 & 9 & 4 & 5 & 6 & 1 & 1 & 2 & 1 \\
\hline Orientus ishidae* & 69 & 22 & 4 & & 7 & 5 & 1 & & 3 & & 2 & & \\
\hline Hyalestes obsoletus* & 27 & 10 & & & 6 & & & & 4 & & & & \\
\hline Hishimonus hamatus* & 2 & 0 & & & & & & & & & & & \\
\hline
\end{tabular}

$\mathrm{z} *$ Indicates that insect numbers refer to batches of one to two individuals. 
the insect specimens that tested positive for $16 \mathrm{SrV}-\mathrm{C}$ phytoplasmas, only one Orientus ishidae was amplified on tufgene, while analyses on $r p$ and $\sec Y$ genes did not show amplification for both Orientus ishidae and $S$. titanus specimens.

BN strains. BN phytoplasma RFLP profiles on tuf, stamp, and secY genes were obtained for three grapevine samples, and three Hyalestes obsoletus batches and four lineages were differentiated. One was detected in two grapevine samples, a second was present in both grapevines and Hyalestes obsoletus, and the last two were observed only in Hyalestes obsoletus (data not shown). However, not all the studied genes could be amplified in grapevines; Hyalestes obsoletus, S. titanus, and Orientus ishidae samples tested positive for the $16 \mathrm{~S} r R N A$ gene.

Other phytoplasmas. Molecular characterization on $r p$ gene was only carried out for phytoplasma strains belonging to $16 \mathrm{SrVI}$ and $16 \mathrm{SrVII}$ ribosomal groups. The four grapevine cultivar Glera samples collected from three vineyards showed restriction profiles identical to each other and to the strain CP (' $\mathrm{Ca}$. P. trifolii', 16SrVIA). Only four of the nine phytoplasma strains identified as belonging to $16 \mathrm{SrVII}$ group amplified on the $r p$ gene (grapevine samples 13B and $3 \mathrm{Y}$, Orientus ishidae batch $3 \mathrm{~B}$, and S. titanus batch $2 \mathrm{~A}(2)$ ) and their RFLP patterns were identical to each other and to the strain (ASHY12) ('Ca. P. fraxini', 16SrVII-A).

Sequencing and phylogenetic analyses. The $16 \mathrm{~S} r R N A, r p$, and tuf gene sequences of selected phytoplasma-positive samples from grapevine and insects were deposited in GenBank (Table 2). Direct sequencing of P1/Tint amplicons from grapevine sample 7B produced a sequence of about $1,800 \mathrm{bp}$ (GenBank accession number KY454858) (Table 2) and showed 99\% homology with a number of strains in 16SrVII (ash yellows group). The analysis of this sequence by $i$ PhyClassifier software showed identity (similarity coefficient 1.00) to the patterns of 16SrVII-A phytoplasma (ASHY4, accession number AF092209); this was confirmed by virtual RFLP analyses with selected restriction enzymes (Fig. 4). The alignment with a number of ash yellows phytoplasma sequences from GenBank showed indeed two nonsynonymous SNPs (position 163 and 630, respectively), differentiating the grapevine $7 \mathrm{~B}$ sequence from all the others. The sequences of about 900 bp obtained from grapevine samples 7A and 9B were identical to each other and to reference strain 16SrVI-A (accession number AY390261) confirming the RFLP results. Phylogenetic analyses on $16 S r$ and $r p$ genes obtained from both grapevine and insect vectors confirmed the clustering of amplicons with sequences from phytoplasmas enclosed in groups 16SrV, 16SrVI, and 16SrVII (Figs. 5 and 6).

\section{DISCUSSION}

The results of this study confirm that GY diseases in one of the most important viticulture areas in Italy (Prosecco wine-making
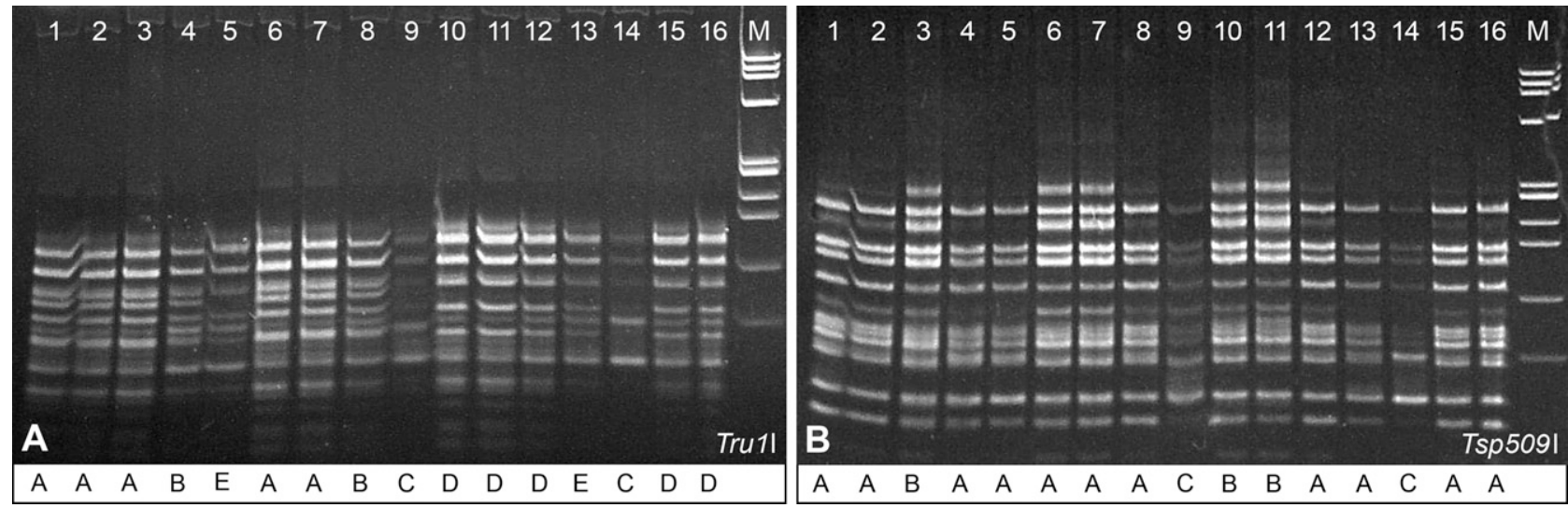

Fig. 3. Restriction fragment length polymorphism (RFLP) patterns of the $\operatorname{rp}(\mathrm{V}) \mathrm{F} 1 \mathrm{~A} / \mathrm{rpR} 1$ amplicons from grapevine samples digested with $\mathbf{A}$, TrulI and $\mathbf{B}$, Tsp509I. Samples: 1, 7 Bariv; 2, Anzano 2; 3, Fonte 3; 4, Crocetta 4; 5, Colle 3; 6, Crocetta 3; 7, Anzano 3; 8, 3 Bar; 9 , 01 MOL; 10, * Bar; 11, 6 Bariv; 12 , Anzano 5; 13, Valdo 1; 14, Colle 7(2); 15, Crocetta 1; 16, 06M. M, marker phiX174 DNA digested with HaeIII length from top to bottom fragments in basepairs: 1,353; 1,$078 ; 872 ; 603 ; 310 ; 281 ; 271 ; 234 ; 194 ; 118 ;$ and 72 . The letters at the bottom are referred to RFLP profiles as reported in Table 2.
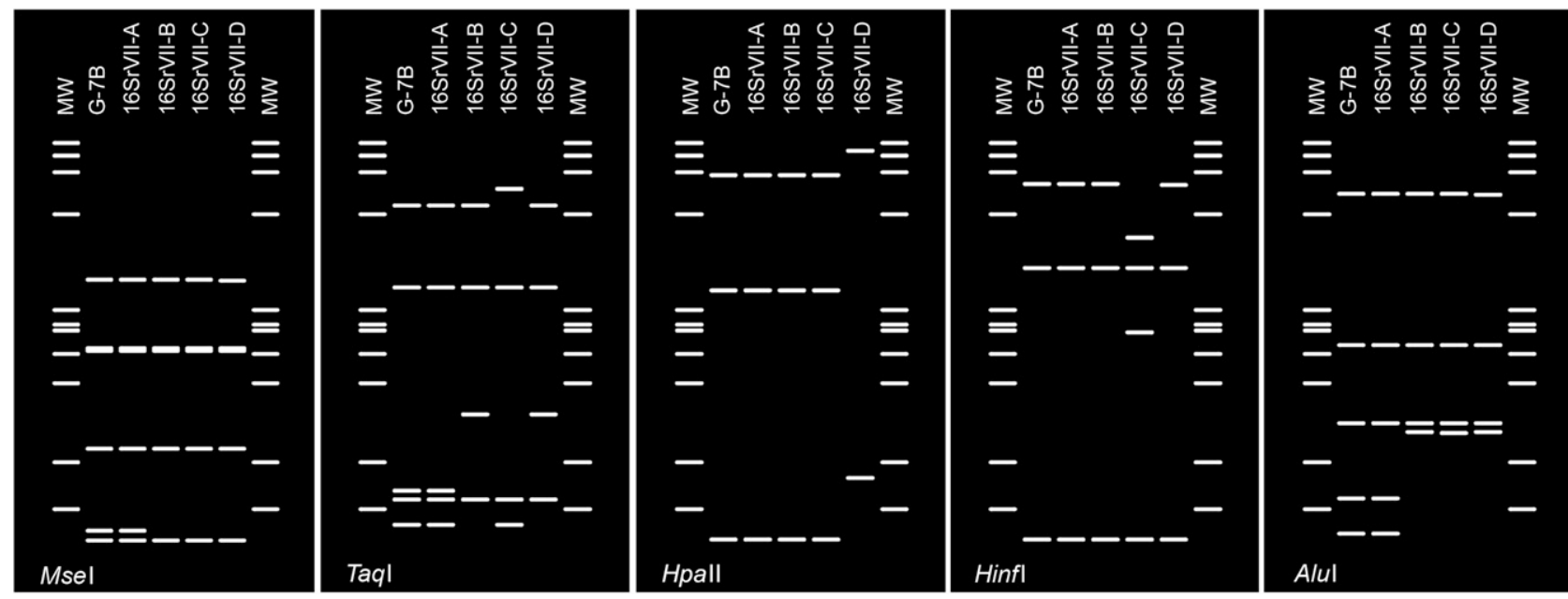

Fig. 4. Virtual restriction fragment length polymorphism analyses on grapevine 7B R16F2n/R2 amplicon (GenBank accession number KY454858) digested with MseI, TaqI, HpaII, HinfI, and AluI in comparison with phytoplasma reference strains belonging to 16SrVII-A (accession number AF09209), 16SrVII-B (accession number AY034608), 16SrVII-C (accession number AY147038), and 16SrVII-D (accession number KJ831066) group using the interactive online tool $i$ PhyClassifier (Zhao et al. 2009). 
area) is associated with the presence of different phytoplasmas and diverse insect vectors. In particular, this 3-year monitoring highlighted a significant percentage of phytoplasma-positive samples from both symptomatic (about 75\%) and asymptomatic (about 40\%) grapevine plants, with the FD strains being the most prevalent independently from the infected cultivar or vineyard considered. However, a decreasing trend in FD presence was observed that is continuing since the first detection studies (Martini

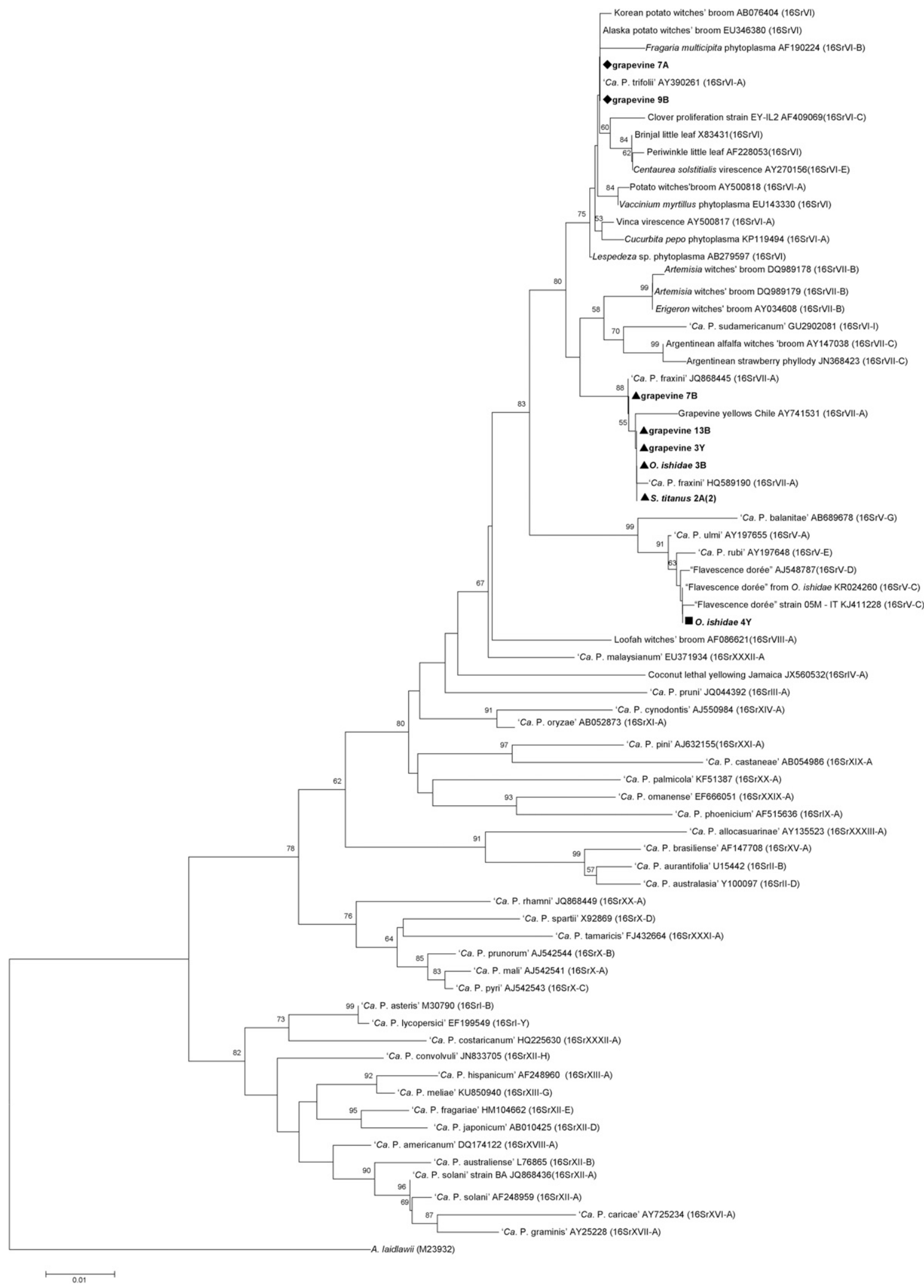

Fig. 5. Phylogenetic tree constructed by maximum parsimony analysis of $16 \mathrm{~S}$ ribosomal DNA sequences from selected phytoplasma strains. The percentage of replicate trees in which the associated taxa clustered together in the bootstrap test (1,000 replicates) are shown above the branches (Felsenstein 1985). The tree is drawn to scale, with branch lengths in the same units as those of the evolutionary distances used to infer the phylogenetic tree. The evolutionary distances were computed using the maximum composite likelihood method (Tamura et al. 2004) and are in the units of the number of base substitutions per site. The GenBank accession numbers for each taxon are given after 'Candidatus' name. The strains sequenced in this work are in bold. 
et al. 1999). The BN phytoplasmas on the contrary showed a slight increase during the survey together with the presence of phytoplasmas belonging to other ribosomal groups. These findings are partly in agreement with the results obtained during the last 20 years of monitoring in this area of the Veneto region that showed a cyclic opposite trend of FD and BN phytoplasmas (Angelini et al. 2006; Canel et al. 2014) and are completely in agreement with those of the 2016 and 2017 testing on other vineyards located in the same areas (A. Bertaccini, unpublished data).

The lack of correlation between phytoplasma group prevalence and location or grapevine cultivar is linked to the particular land shape in which the survey was carried out being narrow hills and small flat areas near to each other that made almost a unique vineyard. The increasing of sampling in the last year of the survey to accommodate the testing of asymptomatic plants in order to verify their possible role as disease reservoirs resulted in the detection mainly of phytoplasmas belonging to groups $16 \mathrm{SrVI}$ and $16 \mathrm{SrVII}-$ A. These are reported already in symptomatic grapevine plants in other viticultural areas where climatic conditions are far different from those in the studied area (Chile, Syria, and Iran) (Contaldo et al. 2011; Gajardo et al. 2009; Zamharir et al. 2017).

Multigene analysis of FD and BN strains revealed the presence of four BN phytoplasma lineages but also a high variability in the FD phytoplasma strains, where five lineages in the $16 \mathrm{SrV}-\mathrm{C}$ and four in the $16 \mathrm{SrV}-\mathrm{D}$ subgroups were detected. The FD variability was mainly found on the $r p$ gene with the new primer combination used in this work, while the $\mathrm{BN}$ strain lineages identified are consistent with previously reported data in other $\mathrm{BN}$-infected areas (Contaldo et al. 2016). The detected genetic heterogeneity among FD phytoplasmas is in agreement with previously reported data in the Italian regions, Emilia-Romagna and Tuscany (Bertaccini et al. 2013; Botti and Bertaccini 2006), France (Martini et al. 2002) and in Serbia (Paltrinieri et al. 2012). The presence of a number of FD variants could be related to an endemic phase of the disease, when the pathogen is subjected to a low selective pressure and consequently to molecular changes especially in some genes like the secY (Bertaccini and Duduk 2009; Lee et al. 2006) and rpS3 (Quaglino et al. 2010) that are influenced by the environmental pressure (Kakizawa et al. 2006).

Furthermore, this situation could be emphasized by the possible role of insects and wild secondary hosts in the epidemiology of the diseases that was reported to lead new ecological niches and diverse phytoplasmas emerging (Lee et al. 1998b). The high percentage of specimens positive for phytoplasmas (ranging between 30 and $50 \%$ ) in the monitoring is in agreement with this situation. The number of Orientus ishidae captured in the selected vineyards was significantly higher than previously reported in North-West Italy and Switzerland, where the insect was quite uncommon and was collected under low density situations (Casati et al. 2017; Trivellone et al. 2015, 2016). Moreover, the three insect species positive for phytoplasmas were carrying different ribosomal groups reported as associated with GY diseases in Chile and Iran (16SrVII) (Gajardo et al. 2009; Zamharir et al. 2017) and occasionally in Syria (16SrVI) (Contaldo et al. 2011).

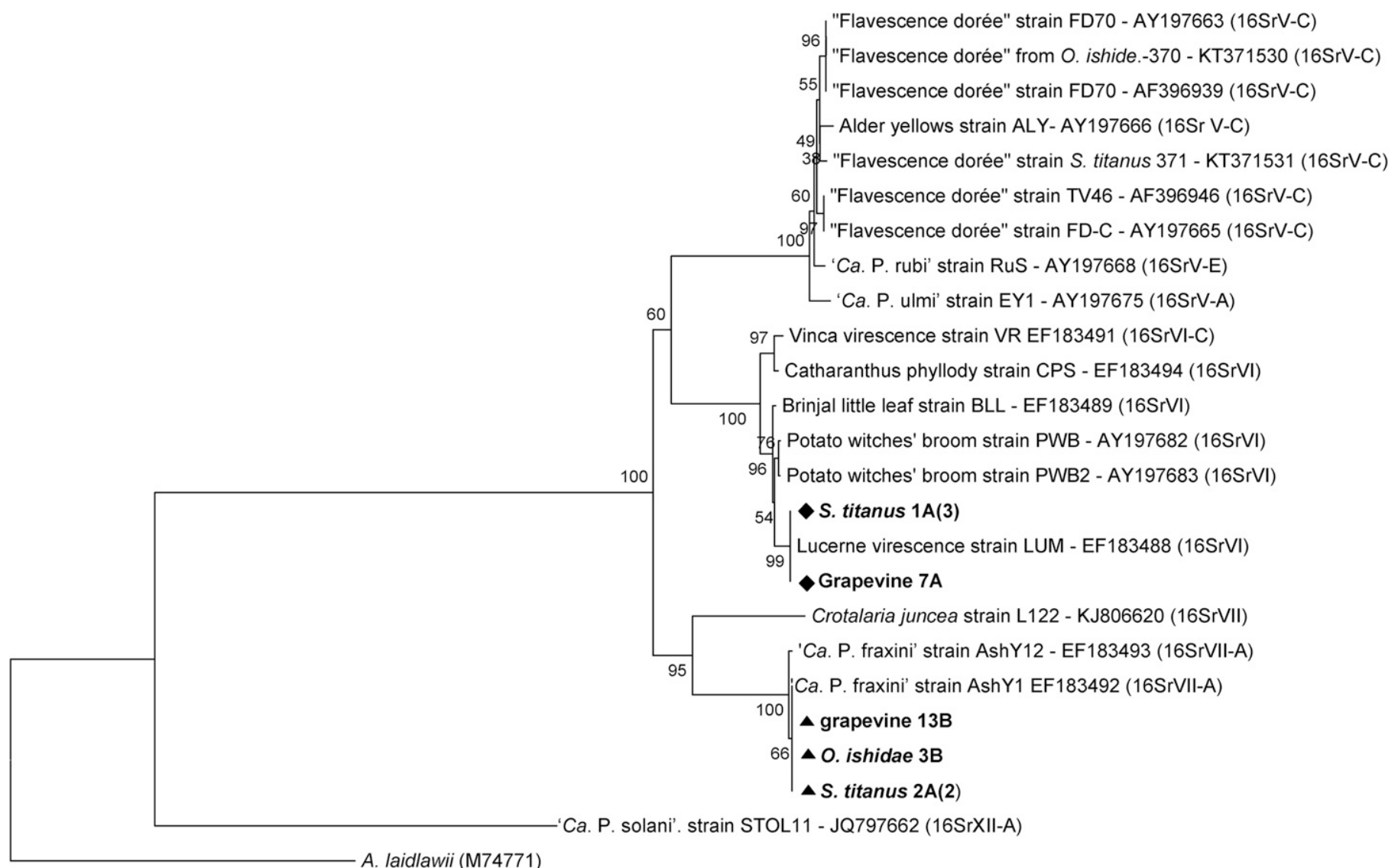

0.05

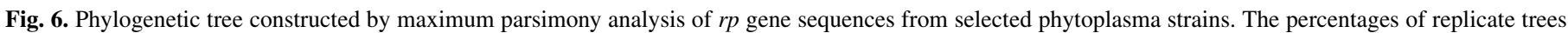

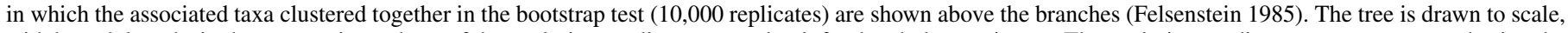

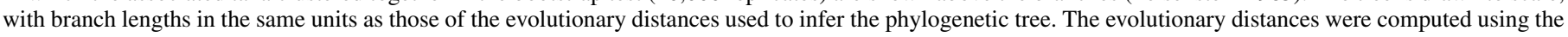

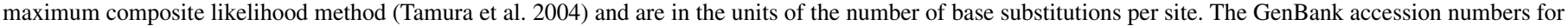
each taxon are given after 'Candidatus' name or strain definition. The strains sequenced in this work are in bold. 
These phytoplasmas are not very commonly detected in Europe; however, 16SrVII phytoplasmas were reported in Italy in peach and Hypericum spp. (Paltrinieri et al. 2002, 2003), while 16SrVI phytoplasmas were detected in Centaurea solstitialis (Faggioli et al. 2004) in Italy, in Vaccinium myrtillus in Austria (Borroto Fernández et al. 2007), and in Rhododendron spp. in the Czech Republic (Pribylova et al. 2009). The surveyed vineyards were surrounded with forests, and most of the insect specimens were collected by traps placed along their borders, confirming that the environmental situation is very important in grapevine GY epidemiology (Dermastia et al. 2017). Orientus ishidae is strictly associated with woody plants such as Acer spp., Betula spp., Carpinus spp., Crataegus spp., apple, Ostrya spp., and salix, and all have been reported as phytoplasma host plants; therefore, a role of this insect in phytoplasma transmission from forest plants to grapevine is very likely, given that it has been demonstrated to be a phytoplasma vector (Lessio et al. 2016). Moreover, the presence of S. titanus, specific ampelophagous insect, infected by both newly identified phytoplasmas (groups 16SrVII and 16SrVI), may indicate a risk of epidemics by these phytoplasmas in the studied vineyards. These phytoplasmas were detected also in asymptomatic plants, confirming the hypothesis of a recent colonization of these grapevine varieties or their tolerance to the presence of these prokaryotes.

This is the first report of phytoplasmas belonging to 16SrVII-A and $16 \mathrm{SrVI}$ groups, never detected before in grapevine, S. titanus and Orientus ishidae in Europe. Epidemiological significance of the Orientus ishidae reported as rapidly colonizing the European environments (Koczoer et al. 2013) and as 16SrV group phytoplasma vector (Lessio et al. 2016), together with the new finding of $16 \mathrm{SrVII}$ and $16 \mathrm{SrVI}$ phytoplasmas, must be further monitored. Moreover, the presence of alternative host plants in the vineyards and in the surrounding forests needs to be investigated to prevent new disease outbreaks by focused management strategies.

\section{ACKNOWLEDGMENTS}

This work was carried out in the frame of European Union's Horizon 2020 research and innovation programme project "Tropicsafe" under grant agreement number 727459 .

\section{LITERATURE CITED}

Angelini, E., Clair, D., Borgo, M., Bertaccini, A., and Boudon-Padieu, E. 2001. Flavescence dorée in France and Italy. Occurrence of closely related phytoplasmas isolates and there near relationships to Palatinate grapevine yellows and an alder yellows phytoplasma. Vitis 40:79-86.

Angelini, E., Filippin, L., Michielini, C., Bellotto, D., and Borgo, M. 2006. High occurrence of flavescence dorée phytoplasma early in the season on grapevines infected with grapevine yellows. Vitis 45:151-152.

Angelini, E., Squizzato, F., Lucchetta, G., and Borgo, M. 2004. Detection of a phytoplasma associated with grapevine flavescence dorée in Clematis vitalba L. Eur. J. Plant Pathol. 110:193-201.

Arnaud, G., Malembic-Maher, S., Salar, P., Maixner, M., Marcone, C., Boudon-Padieu, E., and Foissac, X. 2007. Multilocus sequence typing confirms the close genetic interrelatedness between three distinct flavescence dorée phytoplasma strain clusters and group $16 \mathrm{SrV}$ phytoplasmas infecting grapevine and alder in Europe. Appl. Environ. Microbiol. 73: 4001-4010.

Bertaccini, A. 2014. International Phytoplasmologist Working Group. http:// www.ipwgnet.org/collection

Bertaccini, A., and Duduk, B. 2009. Phytoplasma and phytoplasma diseases: A review of recent research. Phytopathol. Mediterr. 48:355-378.

Bertaccini, A., Duduk, B., Paltrinieri, S., and Contaldo, N. 2014. Phytoplasmas and phytoplasma diseases: A severe threat to agriculture. Am. J. Plant Sci. 5:1763-1788.

Bertaccini, A., Paltrinieri, S., Contaldo, N., Gargani, E., Braccini, P., and Bagnoli, B. 2013. Genetic variability in phytoplasmas associated with flavescence dorée in a vineyard of the Massa Carrara province (Tuscany, Italy). Petria 23:127-130

Bertaccini, A., Vibio, M., and Stefani, E. 1995. Detection and molecular characterization of phytoplasmas infecting grapevine in Liguria (Italy). Phytopathol. Mediterr. 34:137-141.
Borgo, M., Albanese, G., Quaglino, F., Casati, P., Ermacora, P., Ferretti, L., Ferrini, F., Filippin, L., Pasquini, G., and Angelini, E. 2008. Ruolo di altre piante nell'epidemiologia dei fitoplasmi agenti di flavescenza dorata e legno nero. Petria 18:261-263.

Borroto Fernández, E.G., Calari, A., Hanzer, V., Katinger, H., Bertaccini, A., and Laimer, M. 2007. Phytoplasma infected plants in Austrian forests: Role as a reservoir? Bull. Insectol. 60:391-392.

Botti, S., and Bertaccini, A. 2006. FD-related phytoplasmas and their association with epidemic and nonepidemic situations in Tuscany (Italy). XVth ICVG Stellenbosch S. Afr. 3-7:163-164.

Botti, S., and Bertaccini, A. 2007. Grapevine yellows in Northern Italy: Molecular identification of flavescence dorée phytoplasma strains and of bois noir phytoplasmas. J. Appl. Microbiol. 103:2325-2330.

Canel, A., Zambon, Y., Bertaccini, A., Paltrinieri, S., and Contaldo, N. 2014. Flavescenza dorata sotto controllo nel trevigiano. L'Inf. Agric. 20:48-52.

Carraro, L., Ermacora, P., Loi, N., and Osler, R. 2004. The recovery phenomenon in apple proliferation-infected apple trees. J. Plant Pathol. 86:141-146.

Casati, P., Jermini, M., Quaglino, F., Corbani, G., Schaerer, S., Passera, A., and Bianco, P. A. 2017. New insights on flavescence dorèe phytoplasma ecology in the vineyard agro-ecosystem in southern Switzerland. Ann. Appl. Biol. 171:37-51.

Constable, F. E. 2010. Phytoplasma epidemiology: Grapevines as a model. Pages 188-212 in: Phytoplasmas: Genomes, Plant Hosts and Vectors. P. Weintraub and P. Jones, eds. CAB International, Wallingford, UK.

Contaldo, N., Canel, A., Makarova, O., Paltrinieri, S., Bertaccini, A., and Nicolaisen, M. 2011. Use of a fragment of the tuf gene for phytoplasma 16Sr group/subgroup differentiation. Bull. Insectol. 64(suppl.):S45-S46.

Contaldo, N., Zambon, Y., Paltrinieri, S., Mori, N., Mitrovic, J., Duduk, B., and Bertaccini, A. 2016. Characterization of 'Candidatus Phytoplasma solani' strains from grapevines, Hyalesthes obsoletus, reference strains in periwinkle and in colonies. Mitteil. Kloster. 66:63-69.

Deng, S. J., and Hiruki, C. 1991. Amplification of 16S ribosomal-RNA genes from culturable and nonculturable mollicutes. J. Microbiol. Methods 14: 53-61.

Dermastia, M., Bertaccini, A., Constable, F., and Mehle, N. 2017. Grapevine Yellows Diseases and Their Phytoplasma Agents-Biology and Detection. Springer Briefs in Agriculture. Springer International Publishing AG, Switzerland.

Fabre, A., Danet, J. L., and Foissac, X. 2011. The stolbur phytoplasma antigenic membrane protein gene stamp is submitted to diversifying positive selection. Gene 472:37-41.

Faggioli, F., Pasquini, G., Lumia, V., Campobasso, G., Widmer, T. L., and Quimby, P. C., Jr. 2004. Molecular identification of a new member of the clover proliferation phytoplasma group (16SrVI) associated with Centaurea solstitialis virescence in Italy. Eur. J. Plant Pathol. 110:353-360.

Felsenstein, J. 1985. Confidence limits on phylogenies: An approach using the bootstrap. Evolution 39:783-791.

Fialova, R., Valova, P., Balakishiyeva, G., Danet, J. L., Safarova, D., Foissac, X., and Navratil, M. 2009. Genetic variability of stolbur phytoplasma in annual crop and wild plant species in South Moravia. J. Plant Pathol. 91: 411-416.

Filippin, L., Angelini, E., Lucchetta, G., Leandrin, L., and Borgo, M. 2005. Presenza di fitoplasmi nella flora spontanea dei vigneti. Petria 15:77-79.

Filippin, L., Jovic, J., Cvrkovic, T., Forte, V., Clair, D., Tosevski, I., Boudon-Padieu, E., Borgo, M., and Angelini, E. 2009. Molecular characteristics of phytoplasmas associated with flavescence dorée in clematis and grapevine and preliminary results on the role of Dictyophara europaea as a vector. Plant Pathol. 58:826-837.

Foissac, X., and Maixner, M. 2013. Spread of grapevine phytoplasma diseases in Europe.Phytopathol. Moll. 3:47-50.

Gaffuri, F., Sacchi, S., and Cavagna, B. 2011. First detection of the mosaic leafhopper, Orientus ishidae, in northern Italy infected by the flavescence dorée phytoplasma. New Dis. Rep. 24:22.

Gajardo, A., Fiore, N., Prodan, S., Paltrinieri, S., Botti, S., Pino, A. M., Zamorano, A., Montealegre, J., and Bertaccini, A. 2009. Phytoplasmas associated with grapevine yellows disease in Chile. Plant Dis. 93:789-796.

Gibb, K. S., Padovan, A. C., and Mogen, B. D. 1995. Studies on sweet potato little-leaf phytoplasma detected in sweet potato and other plant species growing in Northern Australia. Phytopathology 85:169-174.

Gundersen, D. E., and Lee, I.-M. 1996. Ultrasensitive detection of phytoplasmas by nested-PCR assay using two universal primer pairs. Phytopathol. Mediterr. 35:144-151.

IRPCM. 2004. 'Candidatus Phytoplasma', a taxon for the wall-less, nonhelical prokaryotes that colonize plant phloem and insects. Int. J. Syst. Evol. Microbiol. 54:1243-1255.

Kakizawa, S., Oshima, K., Jung, H.-Y., Suzuki, S., Nishigawa, H., Arashida, R., Miyata, S., Ugaki, M., Kishino, H., and Namba, S. 2006. Positive selection acting on a surface membrane protein of the plant-pathogenic phytoplasmas. J. Bacteriol. 188:3424-3428. 
Koczoer, S., Bagarus, A. K., Karap, A. K., Varga, A., and Orosz, A. 2013. A rapidly spreading potential pest, Orientus ishidae identified in Hungary. Bull. Insectol. 66:221-224.

Langer, M., and Maixner, M. 2004. Molecular characterization of grapevine yellows associated phytoplasmas of the stolbur-group based on RFLPanalysis of non-ribosomal DNA. Vitis 43:191-199.

Lee, I.-M., Bertaccini, A., Vibio, M., and Gundersen, D. E. 1995. Detection of multiple phytoplasmas in perennial fruit trees with decline symptoms in Italy. Phytopathology 85:728-735.

Lee, I.-M., Bottner-Parker, K. D., Zhao, Y., Davis, R. E., and Harrison, N. A. 2010. Phylogenetic analysis and delineation of phytoplasmas based on $\sec Y$ gene sequences. Int. J. Syst. Evol. Microbiol. 60:2887-2897.

Lee, I.-M., Gundersen, D. E., Hammond, R. D., and Davis, R. E. 1994. Use of mycoplasma-like organism (MLOs) group specific oligonucleotide primers for nested-PCR assays to detect mixed-MLO infections in a single host plant. Phytopathology 84:559-566.

Lee, I.-M., Gundersen-Rindal, D. E., and Bertaccini, A. 1998b. Phytoplasma: Ecology and genomic diversity. Phytopathology 88:1359-1366.

Lee, I.-M., Gundersen-Rindal, D. E., Davis, R. E., and Bartoszyk, I. M. 1998a. Revised classification scheme of phytoplasmas based on RFLP analyses of 16S rRNA and ribosomal protein gene sequences. Int. J. Syst. Evol. Microbiol. 48:1153-1169.

Lee, I.-M., Martini, M., Marcone, C., and Zhu, S. F. 2004. Classification of phytoplasma strains in the elm yellows group (16SrV) and proposal of 'Candidatus Phytoplasma ulmi' for the phytoplasma associated with elm yellows. Int. J. Syst. Evol. Microbiol. 54:337-347.

Lee, I.-M., Zhao, Y., and Bottner, K. D. 2006. SecY gene sequence analysis for finer differentiation of diverse strains in the aster yellows phytoplasma group. Mol. Cell. Probes 20:87-91.

Lessio, F., Picciau, L., Gonella, E., Mandrioli, M., Tota, F., and Alma, A. 2016. The mosaic leafhopper Orientus ishidae: Host plants, spatial distribution, infectivity, and transmission of $16 \mathrm{SrV}$ phytoplasma to vines. Bull. Insectol. 69:277-289.

Lessio, F., Tedeschi, R., and Alma, A. 2007. Population dynamics, host plants and infection rate with stolbur phytoplasma of Hyalesthes obsoletus Signoret in north-western Italy. J. Plant Pathol. 89:97-102.

Lim, P. O., and Sears, B. B. 1992. Evolutionary relationship of plant pathogenic mycoplasma-like organism and Acholeoplasma laidlawii deduced from two ribosomal protein gene sequences. J. Bacteriol. 174:2606-2611.

Lorenz, K. H., Schneider, B., Ahrens, U., and Seemüller, E. 1995. Detection of the apple proliferation and pear decline phytoplasmas by PCR amplification of ribosomal and nonribosomal DNA. Phytopathology 85:771-776.

Maixner, M., Ahrens, U., and Seemüller, E. 1995. Detection of the German grapevine yellows (Vergilbungskrankheit) MLO in grapevine, alternative hosts and a vector by a specific PCR procedure. Eur. J. Plant Pathol. 101:241-250.

Maixner, M., Reinert, W., and Darimont, H. 2000. Transmission of grapevine yellows by Oncopsis alni (Schrank) (Auchenorrhyncha: Macropsinae). Vitis 39:83-84.

Makarova, O., Contaldo, N., Paltrinieri, S., Kawube, G., and Bertaccini, A. 2012. DNA barcoding for identification of 'Candidatus Phytoplasmas' using a fragment of the elongation factor $t u$ gene. PLoS One 7:e52092.

Marcone, C., Ragozzino, A., and Seemüller, E. 1997. Identification and characterization of the phytoplasma associated with elm yellows in southern Italy and its relatedness to other phytoplasmas of the elm yellows group. Eur. J. Forest Pathol. 27:45-54.

Martini, M., Botti, S., Marcone, C., Marzachì, C., Casati, P., Bianco, P. A., Benedetti, R., and Bertaccini, A. 2002. Genetic variability among flavescence dorée phytoplasmas from different origins in Italy and France. Mol. Cell. Probes 16:197-208.

Martini, M., Lee, I.-M., Bottner, K. D., Zhao, Y., Botti, S., Bertaccini, A., Harrison, N. A., Carraro, L., Marcone, C., Khan, A. J., and Osler, R. 2007. Ribosomal protein gene-based phylogeny for finer differentiation and classification of phytoplasmas. Int. J. Syst. Evol. Microbiol. 57:2037-2051.

Martini, M., Murari, E., Mori, N., and Bertaccini, A. 1999. Identification and epidemic distribution of two flavescence dorée-related phytoplasmas in Veneto (Italy). Plant Dis. 83:925-930.

Mehle, N., Rupar, M., Seljak, G., Ravnikar, M., and Dermastia, M. 2011. Molecular diversity of flavescence dorée phytoplasma strains in Slovenia. Bull. Insectol. 64(suppl.):S29-S30.

Mehle, N., Seljak, G., Rupar, M., Ravnikar, M., and Dermastia, M. 2010. The first detection of a phytoplasma from the $16 \mathrm{SrV}$ (elm yellows) group in the mosaic leafhopper Orientus ishidae. New Dis. Rep. 22:11.

Padovan, A. C., Gibb, K. S., Bertaccini, A., Vibio, M., Bonfiglioli, R. E., Magarey, P. A., and Sears, B. B. 1995. Molecular detection of the Australian grapevine yellows phytoplasma and comparison with a grapevine yellows phytoplasma from Emilia-Romagna in Italy. Aust. J. Grape Wine Res. 1:25-31.

Paltrinieri, S., Contaldo, N., Duduk, B., and Bertaccini, A. 2012. Strain differentiation in flavescence dorée phytoplasmas on secY and tuf genes. Pages 236-237 in:Proceedings of the 17th Congress of ICVG, Davis, CA.
Paltrinieri, S., Davino, S., Botti, S., Davino, M., and Bertaccini, A. 2003. Identificazione molecolare di fitoplasmi associati ad un deperimento del pesco in Sicilia. Pages 293-296 in: Atti IV Convegno Nazionale sulla Peschicoltura Meridionale. T. Caruso, F. P. Marra, and F. Sottile, eds. Campobello di Licata Agrigento, Italy.

Paltrinieri, S., Tasso, L., Bellardi, M. G., and Bertaccini, A. 2002. Identificazione molecolare di fitoplasmi associati a nanismo e scopazzi in iperico. Petria 12:395-396.

Pollini, A. 2013. Entomologia Applicata, 1st ed. Edagricole-New Business Media, Italy.

Pribylova, J., Petrzik, K., and Spak, J. 2009. The first detection of 'Candidatus Phytoplasma trifolii' in Rhododendron hybridum. Eur. J. Plant Pathol. 124: 181-185.

Prince, J. P., Davis, R. E., Wolf, T. K., Lee, I.-M., Mogen, B. D., Dally, E. L., Bertaccini, A., Credi, R., and Barba, M. 1993. Molecular detection of diverse mycoplasma-like organisms (MLOs) associated with grapevine yellows and their classification with aster yellows, $\mathrm{X}$-disease, and elm yellows MLOs. Phytopathology 83:1130-1137.

Quaglino, F., Casati, P., and Bianco, P. A. 2010. Distinct rpsC single nucleotide polymorphism lineages of flavescence dorée subgroup $16 \mathrm{SrV}-\mathrm{D}$ phytoplasma co-infect Vitis vinifera L. Folia Microbiol. (Praha) 55:251-257.

Quaglino, F., Zhao, Y., Casati, P., Bulgari, D., Bianco, P. A., and Wei, W. 2013. 'Candidatus Phytoplasma solani', a novel taxon associated with stolbur and bois noir-related diseases of plants. Int. J. Syst. Evol. Microbiol. 63: 2879-2894.

Saitou, N., and Nei, M. 1987. The neighbor-joining method: A new method for reconstructing phylogenetic trees. Mol. Biol. Evol. 4:406-425.

Schneider, B., Seemüller, E., Smart, C. D., and Kirkpatrick, B. C. 1995. Phylogenetic classification of plant pathogenic mycoplasma-like organisms or phytoplasmas. Page 369-380 in: Molecular and Diagnostic Procedures in Mycoplasmology, vol. 1. S. Razin and J. G. Tully, eds. Academic Press, San Diego, CA.

Schvester, D., Carle, P., and Moutous, M. 1961. Sur la transmission de la flavescence dorée des vignes par une cicadelle. C.R. Acad. Agric. Fr. 47:1021-1024.

Sforza, R., Clair, D., Daire, X., Larrue, J., and Boudin-Padieu, E. 1998. The role of Hyalesthes obsoletus (Hemiptera: Cixiidae) in the occurrence of bois noir of grapevines in France. J. Phytopathol. 146:549-556.

Škorić, D., Šarić, A., Vibio, M., Murari, E., Krajačić, M., and Bertaccini, A. 1998. Molecular identification and seasonal monitoring of phytoplasmas infecting Croatian grapevines. Vitis 37:171-175.

Smart, C. D., Schneider, B., Blomquist, C. L., Guerra, L. J., Harrison, N. A., Ahrens, U., Lorenz, K. H., Seemüller, E., and Kirkpatrick, B. C. 1996. Phytoplasma-specific PCR primers based on sequences of the 16-23S rRNA spacer region. Appl. Environ. Microbiol. 62:2988-2993.

Staden, R., Beal, K. F., and Bonfield, J. K. 2000. The Staden package, 1998. Methods Mol. Biol. 132:115-130.

Tamura, K., Nei, M., and Kumar, S. 2004. Prospects for inferring very large phylogenies by using the neighbor-joining method. Proc. Natl. Acad. Sci. USA 101:11030-11035.

Tamura, K., Stecher, G., Peterson, D., Filipski, A., and Kumar, S. 2013. MEGA6: Molecular evolutionary genetics analysis version 6.0. Mol. Biol. Evol. 30:2725-2729.

Thompson, J. D., Gibson, T. J., Plewniak, F., Jeanmougin, F., and Higgins, D. G. 1997. The CLUSTAL X windows interface: Flexible strategies for multiple sequence alignment aided by quality analysis tools. Nucleic Acids Res. 25:4876-4882.

Thompson, J. D., Higgins, D. G., and Gibson, T. J. 1994. Clustal W: Improving the sensitivity of progressive multiple sequence alignment through sequence weighting, position-specific gap penalties and weight matrix choice. Nucleic Acids Res. 22:4673-4680.

Trivellone, V., Filippin, L., Jermini, M., and Angelini, E. 2015. Molecular characterization of phytoplasma strains in leafhoppers inhabiting the vineyard agroecosystem in Southern Switzerland. Phytopathol. Moll. 5 (1-Suppl.):S45-S46.

Trivellone, V., Filippin, L., Narduzzi Wicht, B., and Angelini, E. 2016. A regional-scale survey to define the known and potential vectors of grapevine yellows phytoplasmas in vineyards in South of Swiss Alps. Eur. J. Plant Pathol. 145:915-927.

Wei, W., Davis, R. E., Lee, I.-M., and Zhao, Y. 2007. Computer-simulated RFLP analysis of 16S rRNA genes: Identification of ten new phytoplasma groups. Int. J. Syst. Evol. Microbiol. 57:1855-1867.

Weintraub, P. G., and Beanland, L. 2006. Insect vectors of phytoplasmas. Annu. Rev. Entomol. 51:91-111.

Zamharir, M. G., Paltrinieri, S., Hajivand, S., Taheri, M., and Bertaccini, A. 2017. Molecular identification of diverse 'Candidatus Phytoplasma' species associated with grapevine decline in Iran. J. Phytopathol. 165:407-413.

Zhao, Y., Wei, W., Lee, I.-M., Shao, J., Suo, X., and Davis, R. E. 2009. Construction of an interactive online phytoplasma classification tool, $i$ PhyClassifier, and its application in analysis of the peach $\mathrm{X}$ disease phytoplasma group (16SrIII). Int. J. Syst. Evol. Microbiol. 59:2582-2593. 